\title{
Authentic assessment for academic performance: study on the attitudes, skills, and knowledge of grade 8 mathematics students
}

\section{Widodo Winarso}

Department of Mathematics Education, Syekh Nurjati Islamic State University, Bandung, Indonesia

Corresponding author : widodoiain@gmail.com

\section{ARTICLE HISTORY}

Received May 10, 2018

Revised June 5, 2018

Accepted July 2, 2018

\section{KEYWORDS}

Authentic Assessment Academic Performance Mathematical

\begin{abstract}
The purpose of the this research is: (1) To know the quality of the mathematics learning outcomes that apply a authentic assessment, (2) To know the student's response to the application of an authentic assessment of mathematics learning. This study uses a quantitative method of causal-comparative type, using test instruments, questionnaires and observations. The object of this study is conditioned in 2 classes, control class (Class 8B) and experiment class (Class 8E). The results showed that the application of the authentic assessment used by teachers is good. On the basis of the data obtained, it is known that the result of learning two classes (control class and experiment class) on attitudinal aspects and skills has the same relative quality. While the learning outcomes on the knowledge aspect, the maximum value reached by the experimental class is higher than the control class (from 72.5 to 65). The effect of treatment on the experimental class is low, indicated by the value of ES (effect size) obtained equal to 0.3 . The result of the study based on the student's response level shows that there are 7 students who have a low response to the learning activity (18\%), 23 students have an average response to the learning activities (61\%) and 8 students have a high response to learning activities. Two other categories, none of the students had very low and very high responses to learning activities $(0 \%)$. This study also confirmed that Ho was rejected and Ha was accepted, so it can be concluded that there are differences in mathematics learning outcomes among students who use authentic assessment with students who do not use authentic assessment.
\end{abstract}

\section{INTRODUCTION}

The education is a human need because education is an effort to provide knowledge, intuition, skills, certain adeptness to individuals in order to develop their potential so that they can handle any changes that occur due to the progress of science and of technology (Pellegrino \& Hilton, 2012). Therefore, to create quality education requires better efforts to solve problems, a constant and regular assessment and continuous innovation. Every effort that has been made will lead to the achievement of quality education as expected, and ultimately to contribute positively to the education of Indonesia in general.

Successful learning is a condition achieved by teachers' efforts to teach students, while students try to master the skills they have been taught (Hill, Rowan, and Ball, 2005). The efforts of teachers and students will be known by the conditions of successful learning, so as to obtain information on the effectiveness and efficiency of the learning activities carried out together between teachers and students. The ability and absorption of students is a condition possessed by students in mastering a set of materials or a set of skills that deliberately taught. This condition can be known from the assessment of the learning effort that has been made by the teacher. The recommended evaluation based on Permendiknas (regulation of national education minister) no. 22 of 2006 on Standard Isi (content standards) is an authentic assessment.

The same thing has also been mentioned in Permendiknas no. 16 of 2007 that in the learning activities, assessment is an important element that must be mastered by a teacher in carrying out his duties at school. Moreover, in Permendiknas no. 20 of 2007, it states that education assessment is the process of gathering and processing information to determine the achievement of student learning outcomes. Evaluation of learning outcomes conducted by teachers using a variety of assessment techniques, such as tests, observations, individual assignments or groups, etc, accordance with the characteristics of student competence and level of student development. Referring to the regulation, evaluation is an activity to provide continuous and complete information on the process and results that have been achieved by the students (Clotfelter, Ladd and Vigdor, 2006). In other words, evaluation is not carried out only at the end of the period but is carried out in an integrated way by learning activities in the sense that the progress of learning is judged by the process rather than simply the result (Bergström, 2010).

Similar to the concept of evaluation, an evaluation activity in education is the evaluation of learning (Klopfer, 1971). This activity is carried out by a teacher at least to know: (1) the 
success of the learning that has been done; (2) the ability of students to absorb the material that has been learned; and (3) valuable information such as feedback to teachers in improving the learning activities that have been done. Conceptually authentic assessments are more meaningful than even standardized multiple choice tests. Meanwhile, in applying authentic assessments to find out student outcomes and achievements, teachers must apply criteria related to knowledge construction, observing and performing activities, and external performance values. In the process, the authentic assessment is a student assessment that emphasizes what should be assessed, both the process and the results with various assessment instruments adapted to competencies in the Competency Standards (SK) or Core Competencies (KI) and Basic Competencies (KD) (Kunandar, 2013).

Authentic assessment accurately measures students' skills about the condition of a person who has studied, so that assessment methods or techniques can be able to verify the progress of their skills. Authentic assessment should be able to present real-world challenges, so students must use the relevant skills and knowledge. The authentic assessment is carried out by the teacher in the form of a class assessment. This assessment determines the level of mastery of students on a defined skill. This assessment is internal and part of learning. Authentic assessment is also an ingredient to improve the quality of learning outcomes. This assessment is carried out with the orientation to the competence, referring to the benchmark, learning the mastery and done in various ways. The authentic evaluation can be done through the evaluation of performance (work output), portfolio (student work), assignments (project), performance (performance) and self-evaluation (Stiggins, 1994).

Meanwhile, on the other hand, the main problem in learning in formal education (school) today is still low absorption of students (Muis \& Edwards, 2009). This is evident from the average learning outcomes of the students who are always very alarming. This result is certainly the result of learning conditions that are still centered on the teacher and do not touch the realm of students' own dimensions (Trianto, 2009). The condition is also exacerbated by many students who have not yet fully understood the concepts, while the understanding of mathematical concepts is very important (Meyer \& Land, 2003; Meltzer, 2002). This may be due to the lack of motivation of the students in the learning of mathematics, as well as in the learning activities of the mathematics less active participation of the students, also in the learning that still uses the model of teaching the lessons, as well as in terms of evaluation it is the final madness.

Indeed, the understanding of mathematics lessons required a learning process and learning products or often called learning outcomes. The learning process is systematically done and has a link so that students can master and apply in everyday life. Moreover, in learning mathematics, students not only receive knowledge but are also required to build knowledge with various learning activities, so that learning becomes more meaningful and can be applied in student life (Sa'dijah, 2009 ). Furthermore, the image of the development of student learning must be known by the teacher in order to ensure that the students correctly experience the learning process. If the data collected by the teacher indicates that the student has learning problems, the teacher can immediately take appropriate measures to address the problem of the student. The collected data should be obtained from the real activities that the students make during the learning process (Trianto, 2009).
There is no exception, the learning of mathematics in the cube subjects is necessary to activate and skill the students how to draw, make networks, realize props to calculate the surface area and the volume of the cube, so that in the subject of the cubes students should have skills to improve students' learning outcomes (Gittler \& Glück, 1998; Klein, Beman \& Smith, 2003;). Furthermore, the right strategy for learning and evaluating mathematics is necessary, so that teachers can measure the results of student learning as a whole learning activity. Evaluation is carried out either on the trial or product or student learning result so that all the student's efforts have made an assessment. In this context, authentic assessment becomes one of the solutions for evaluating students during the mathematics learning process.

Based on the problem, in such a way that the formulation of the problem becomes this research; How does the application of authentic evaluation in mathematics learning? How are the results of mathematical learning applying an authentic evaluation? And How does the student's response to applying an authentic evaluation of mathematics learning ?.

\section{METHOD}

This research was conducted at Secondary School 2 Lemahabang Cirebon. This research uses a quantitative method of causal-comparative type (Mertens, 2014), with design only post-test design (Fraenkel, Wallen, \& Hyun, 1993). The population of this study consisted of all eighth-grade students. This sampling technique in this study used Cluster Random Sampling, ie the researchers took a random sample from the group, in which case the group was considered a study group (Kothari, 2004). The researchers used a lottery method to determine the sample (Kothari, 2004). In order to obtain the 8B class as a control class (no less than 76 students) and $8 \mathrm{E}$ class as an experimental class (up to 38 students). Data collection is grouped into three main phases of this study, namely: (1) class observation in the application of the authentic evaluation; (2) Analysis of post-test data; (3) Analysis of the student's response to learning. Regarding the third phase of the order is presented in table 1 .

Table 1. Data collection techniques

\begin{tabular}{lll}
\hline \multicolumn{1}{c}{ Data Type } & \multicolumn{1}{c}{ Method } & \multicolumn{1}{c}{ Instrument } \\
\hline & Quality of learning outcomes \\
\hline $\begin{array}{l}\text { Aspects of } \\
\text { knowledge }\end{array}$ & $\begin{array}{l}\text { Test (type } \\
\text { post-test) }\end{array}$ & $\begin{array}{l}\text { a sheet of } \\
\text { measurable; } \\
\text { indicators of } \\
\text { competence }\end{array}$ \\
\hline $\begin{array}{l}\text { Aspects of } \\
\text { attitude }\end{array}$ & Observation & $\begin{array}{l}\text { observation } \\
\text { guidelines }\end{array}$ \\
\hline Aspects of skill & Observation & $\begin{array}{l}\text { observation } \\
\text { guidelines }\end{array}$ \\
\hline & & $\begin{array}{l}\text { scoring } \\
\text { questionnaire } \\
\text { Responses }\end{array}$ \\
students & Questionnaire & certain \\
\hline
\end{tabular}

The test used in this study is a test form developed by researchers. The development of tests adopted by the concept of geometry learning in secondary schools (Van de Walle, Karp \& Williams, 2007) and the development of the descriptive test (Ennis, \& Weir, 1985; Detlefsen, 2013). 
Tabel 2. Grid instrument main test cube
Basic competencies
Indicator

\begin{tabular}{|c|c|}
\hline \multirow[b]{2}{*}{$\begin{array}{l}\text { Identify the properties } \\
\text { of the cube }\end{array}$} & Mention the elements of the cube \\
\hline & $\begin{array}{l}\text { Determine the diagonal length of } \\
\text { the sides and diagonals of the } \\
\text { cube space }\end{array}$ \\
\hline Creating cube nets & $\begin{array}{l}\text { Make cube nets with objects } \\
\text { around }\end{array}$ \\
\hline \multirow{2}{*}{$\begin{array}{l}\text { Calculates surface } \\
\text { area and cube volume }\end{array}$} & $\begin{array}{l}\text { Calculates the surface area of the } \\
\text { cube }\end{array}$ \\
\hline & Calculates the volume of the cube \\
\hline
\end{tabular}

The observations were used to measure students mathematics learning outcomes in terms of attitude and ability (Bloom, 1956, Driscoll, 2000). What follows is a guideline for observing aspects of aptitude and abilities.

Table 3. Guidelines aspect observation learning outcomes attitude

\begin{tabular}{ll}
\hline Components & \multicolumn{1}{c}{ Indicator } \\
\hline $\begin{array}{l}\text { Attitude } \\
\text { Curiosity }\end{array}$ & Enthusiasm looking for answers \\
\cline { 2 - 2 } Honest attitude & Asking every Iangkah activity. \\
\cline { 2 - 2 } & $\begin{array}{l}\text { No cheatingin doing the testquiz } \\
\text { Create reports based on data or } \\
\text { information about what their }\end{array}$ \\
\hline \multirow{3}{*}{$\begin{array}{l}\text { Attitude } \\
\text { discipline }\end{array}$} & $\begin{array}{l}\text { Obey the rules or the rules of joint/ } \\
\text { school }\end{array}$ \\
\cline { 2 - 2 } $\begin{array}{l}\text { Attitude } \\
\text { responsibility. }\end{array}$ & $\begin{array}{l}\text { Working/collect duties in accordance } \\
\text { with the specified time }\end{array}$ \\
\hline $\begin{array}{l}\text { In collaboration } \\
\text { Attitudes }\end{array}$ & Accepting the risk of the action taken \\
\cline { 2 - 2 } & Willingness perform tasks as agreed \\
\hline
\end{tabular}

Table 4. Guidelines aspect Observation Skills Learning Outcomes

\begin{tabular}{ll}
\hline \multicolumn{1}{c}{ Components } & \multicolumn{1}{c}{ Indicator } \\
\hline \multirow{2}{*}{ Viewing } & Observing nature/identity of the object \\
\cline { 2 - 2 } Comparing & Use/gather the relevant facts \\
\hline \multirow{2}{*}{ Llassify } & Cooking for differences and similarities. \\
\hline \multirow{2}{*}{ Measure } & Noting each observation into a table \\
\cline { 2 - 2 } & Object data classify \\
\cline { 2 - 2 } Communicating & Analyze data \\
\cline { 2 - 2 } & Describing/interpret the data \\
\hline
\end{tabular}

The questionnaire used in the form of a closed questionnaire using the Likert scale (Chang, 1994), is used to determine the student's response to the application of authentic evaluation. Questionnaire with alternative answers that have been provided, namely: SA = Strongly Agree; A = Accept; D = Double; NA= I do not accept; $\mathrm{SD}=$ Strongly disagree.
The hypothesis in this study is a comparative hypothesis. The hypothesis test used is the t-test (T-test for independent samples). But before testing hypotheses, it is necessary to test the prerequisite that includes the normality test and the homogeneity test. If critical thinking data is distributed normally, the test continues with homogeneity testing and hypothesis testing that is testing for two independent samples. On the contrary, if the critical thinking data obtained by the students are not distributed normally, the test is continued with homogeneity test and hypothesis test which is test Mann Whitney U.

After successfully testing the hypothesis with a certain level of significance, the next discussion is the size of the effect. Effective contributions explain what percentage of treatment donations are given in increasing scores in the experimental group. The actual contribution (effect size, abbreviated ES) shows to what extent the effectiveness of the treatment is given and can be expressed in the Cohen-D coefficient (Widhiarso, 2011). If the calculated value of $d$-Cohen was obtained, it can be interpreted by observing the standard values in Table 4 .

Table 5. Values d-Cohen (Becker, 2000)

\begin{tabular}{lccc}
\hline $\begin{array}{c}\text { Cohen's } \\
\text { Standard }\end{array}$ & ES & $\begin{array}{c}\text { Percentile } \\
\text { Standing }\end{array}$ & $\begin{array}{c}\text { Percent of } \\
\text { Nonoverlap }\end{array}$ \\
\hline Small & 0.1 to 0.3 & $54-62$ & $7.7 \%-21.3 \%$ \\
\hline Medium & 0.4 to 0.5 & $66-69$ & $27 \%-33 \%$ \\
\hline of the & ES $\geq 0.6$ & PS $\geq 73$ & PNO $\geq 38 \%$ \\
\hline
\end{tabular}

\section{RESULTS AND DISCUSSION}

\subsection{Academic performance on aspects of attitude}

The attitude is an internal or subjective evaluation process that takes place within a person and can not be directly observed. Attitudes can be known through knowledge, beliefs, feelings and the tendency of one's behavior towards the object of the attitude. The depth of one's attitude towards the object can be measured through his knowledge, his feelings and the way he handles the object. Attitude is a concept consisting of three components, namely cognitive, affective and behavioral. The cognitive component contains all the thoughts and ideas related to the object of the attitude. The contents of one's thought include things that are known about the object of the attitude, they can be an answer or a belief, an impression, an attribution and an evaluation of the attitude object (Istiqomah \& Kariyoso, 2002).

In line with this opinion, according to McLeod \& Adams (2012), there are two factors that can influence the learning process of mathematics in each student, namely: (1) cognitive factors and (2) non-cognitive (affective) factors. Cognitive factors are related to the brain's ability to think. Examples of reasoning skills. Non-cognitive (affective) factors are related to ability beyond the brain's ability to think. for example feeling happy or not happy to learn math. The same thing also supported by Wardhani (2004) that the affective component also determines the success of mathematics for student learning. Further said there are some emotional components, one of which is the attitude. Attitude is a character of a person who describes their positive and negative feelings about an object, situation, institution, person or idea (Nitko \& Brookhart, 2007).

The results data showed that the result of learning on the attitude aspect in class $8 \mathrm{~B}$ (control class) and class $8 \mathrm{E}$ (experimental class) if compared, the quality is relatively equal. 


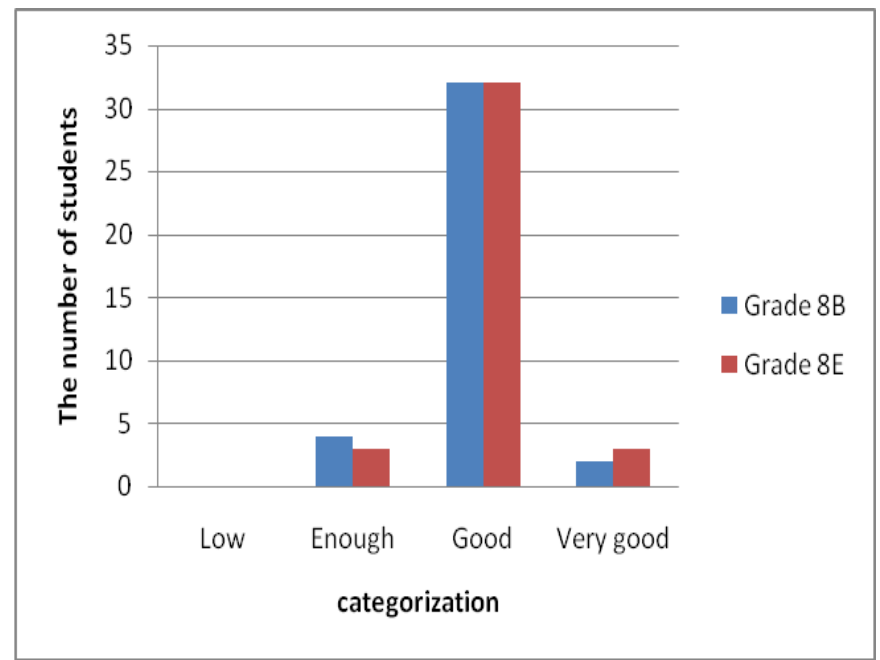

Fig. 1. Comparison of learning outcomes (Aspect Attitude)

Based on Fig. 1 it can be explained that from the number of samples of each class (class $8 \mathrm{~B}$ and class $8 \mathrm{E}$ ) there are 38 students there are 4 students (grade $8 \mathrm{~B}$ ) and 3 students (grade 8E) classified "Basta"; 32 students (grade 8B) and 32 students (grade $8 \mathrm{E}$ ) are classified as "good"; 2 students (grade 8B) and 3 students (grade 8E) who have classified "Very good". As far as the "Low" category is concerned, it is not in the two classes.

However, the fact that contradictory facts on the field show that to date most students are still negative about mathematics. According to Boediono (2004) statistics are a dreaded lesson, avoided and considered difficult for students and students who see mathematics, even people have made statistics and mathematics as a scourge in everyday life. The same thing was also revealed by Breen (2001) that reality for all levels of school, many students who are negative about mathematics, students consider mathematics as a field of study difficult to learn, they are afraid of mathematics. Of course, students' negative opinions or attitudes to mathematics affect the way students learn mathematics. Thus, it is suspected that students' negative attitudes towards mathematics are an indicator of the cause of low student learning outcomes.

\subsection{Academic performance on the appearance of skills}

According to Cragg \& Gilmore (2014), aspects of skills that can be developed in mathematics, in particular, include 5 components, namely: (1) observe, use the five senses to collect data and use relevant facts; (2) Compare (comparison and contrast), discover the similarities and differences of the observed object; (3) Classification, linking of observations, contrasting characteristics and identification of reasons for grouping; (4) Measurement (measurement), using standard measuring instruments (units of length, time, weight) to measure an object during a quantitative observation; (5) Communicate, present ideas or ideas both orally and in writing, reading diagrams, drawings, tables and discussing the results of activities or observations of an event.

The results data showed that the learning outcomes in the appearance of the skills in class $8 \mathrm{~B}$ (control class) and class $8 \mathrm{E}$ (experimental class) if compared, the quality is relatively the same.

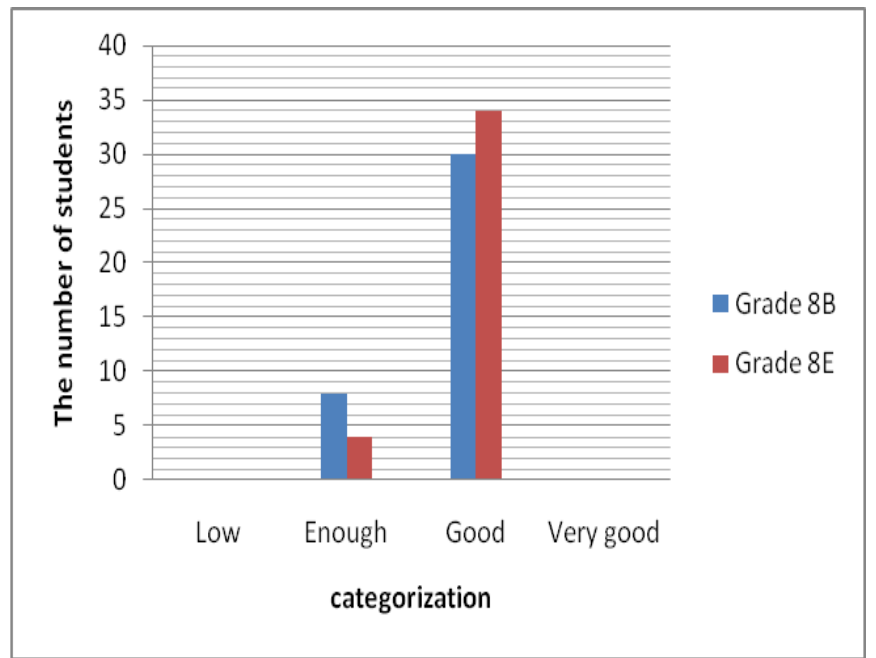

Fig 2. Comparison of learning outcomes (Aspect Skills)

Based on Figure 2, it can be explained that from the number of samples of each class (class $8 \mathrm{~B}$ and $8 \mathrm{E}$ ) up to 38 students there are 8 students (grade $8 \mathrm{~B}$ ) and 4 students (grade $8 \mathrm{E}$ ) classified as "Basta"; 30 students (grade 8B) and 34 students (class 8E) are classified as "good". While in the "Very good" and "Low" category, it is not in the two classes.

\subsection{Academic performance on the aspect of knowledge}

Associated with the aspect of knowledge, how students respond to mathematical problems (for example), known as the posed problem. according to Darnati (2001) the problem of the pose is the formulation of the problem or working on the problem of an available situation, both before, when, and after the resolution of the problems. Another term that corresponds to the problem of the pose is the deposit of problems with the tools that teachers must have to encourage and train students in the formulation of mathematical questions and then determine the agreement. This approach is more emphasized on the training of the activities carried out by the students themselves. This provides students with ample opportunities to build knowledge in accordance with the development of their thinking knowledge (Kusumah, 2004).

In mathematics learning, the problem posed by Silver \& Cai (2005), that is, through discussion, constitutes the interaction between teacher and student. The model of interaction between teachers and students in learning is essentially a relationship between two equal parts, namely that both teachers and students act as learning subjects (Suherman, 2003: 8). Students will acquire more learning experience if actively involved in learning, so it will be necessary to implement learning in a student-centered framework.

Research results related to learning outcomes in the knowledge aspect require different phases of analysis. First of all, to know that the data is normal or not distributed, the normal test will be performed. Here are the results of the normal data processing test of the experimental class and control class

Table 6. Normality test data post-test control class and class experiment 


\begin{tabular}{cccccccc}
\hline \multicolumn{10}{c}{ Tests of Normality } \\
\hline \multirow{2}{*}{ Group } & \multicolumn{1}{c}{ Kolmogorov-Smirnov } & \multicolumn{4}{c}{ Shapiro-Wilk } \\
\cline { 2 - 8 } & Stat & df & Sig. & Stat & df & Sig. \\
\hline (grade 8B) & 0,228 & 38 & 0,000 & 0,879 & 38 & 0,001 \\
\hline (grade 8E) & 0,130 & 38 & 0,102 & 0,927 & 38 & 0,016 \\
\hline
\end{tabular}

\section{a. Lilliefors Significance Correction}

Based on table 6 . The results of the post-test value of the data processing of the experimental class and of the control class above have obtained the result that the significance value of the control class is 0.00 while the significance value of the experimental class it's 0.102 . The significance value of the control class is less than 0.05 , therefore, it means having data obtained from abnormal populations. Because the significance value of the experimental class is greater than $0.05(0.102$ $<0.05)$, then, based on Ho's test criteria, it is rejected which means that the student's post-test value data come from the normally distributed population.

Secondly, the homogeneity test is used to find out if the population of data obtained through the test results of the knowledge learning aspects in solving the geometry problem has a data population of the equal or different variant. Results of homogeneity tests obtained from the data as follows:

Table 7. Test Data Homogeneity Post-Test Control Class and Class Experiment

\begin{tabular}{lcccc}
\hline \multicolumn{4}{c}{ Test of Homogeneity of Variance } \\
\hline Items & $\begin{array}{r}\text { Levene } \\
\text { Statistic }\end{array}$ & df1 & df2 & Sig. \\
\hline Based on Mean & 3,972 & 1 & 74 & 0,05 \\
\hline Based on Median & 3,466 & 1 & 74 & 0,07 \\
\hline Based on trimmed mean & 3,955 & 1 & 74 & 0,05 \\
\hline
\end{tabular}

Based on table 7. Looking at output there is a description of Based on Mean, a significant value of 0.05 is equal to the pre-requisite value of 0.05 . therefore it is assumed that this shows the data of both classes with non-homogeneous variance. Based on this, the authors test the difference between the two-part statistic with a non-parametric test using the Mann-Withney test method.

In the third phase, the results of the Mann-Withney Test (two tests of average difference on two sides) with $a=5 \%(0.05)$, with the following results:

Table 8. Results of Mann-Whitney

\begin{tabular}{cccc}
\hline \multicolumn{4}{c}{ Ranks } \\
\hline Group & $\mathrm{N}$ & Mean Rank & Sum of Ranks \\
\hline 1 (grade 8B) & 38 & 32,45 & 1.233 \\
\hline 2 (grade 8E) & 38 & 44,55 & 1.693 \\
\hline Total & 76 & & \\
\hline
\end{tabular}

\begin{tabular}{lr}
\hline \multicolumn{2}{c}{ Test Statisticsa $^{\mathrm{a}}$} \\
\hline & value \\
\hline Mann-Whitney U & 492 \\
\hline Wilcoxon W & 1.233 \\
\hline$Z$ & $-2,423$ \\
\hline Asymp. Sig. (2-tailed) & 0,015 \\
\hline a. Grouping Variable: Grup & \\
\hline
\end{tabular}

Table 8. shows the average or average value of each group, ie in group 1 (control class) is lower than the second group (experimental class) with the value of $32.45<44.55$. Furthermore, it can also be seen in the Test Statistical output where the test value of Asymp statistics sig. (2-tailed) is $0.015<$ 0.05 . Therefore the test results are statistically significant, so the hypothesis (Ho) is rejected, where there is a difference in the distribution of the scores of the experimental classes and the control classes. It also shows that the use of the "authentic assessment" method in the $8 \mathrm{E}$ class influences the learning outcomes of the students.

From the results of the Mann-Whitney test seen from Rank's output, which indicates that the mean value for the experimental class (class 8E) is greater than the average of the control class (class 8B) $(61.05>57.37)$. While the value of the Mann-Whitney U test, we can see the output "Test Statistic" where the test value of the statistics of Asymp sig. (2-tailed) is $0.015<0.05$. Therefore the test results are statistically significant, so the Hypothesis (Ho) is rejected, where there is a difference in the distribution of scores between the experimental class and the control class.

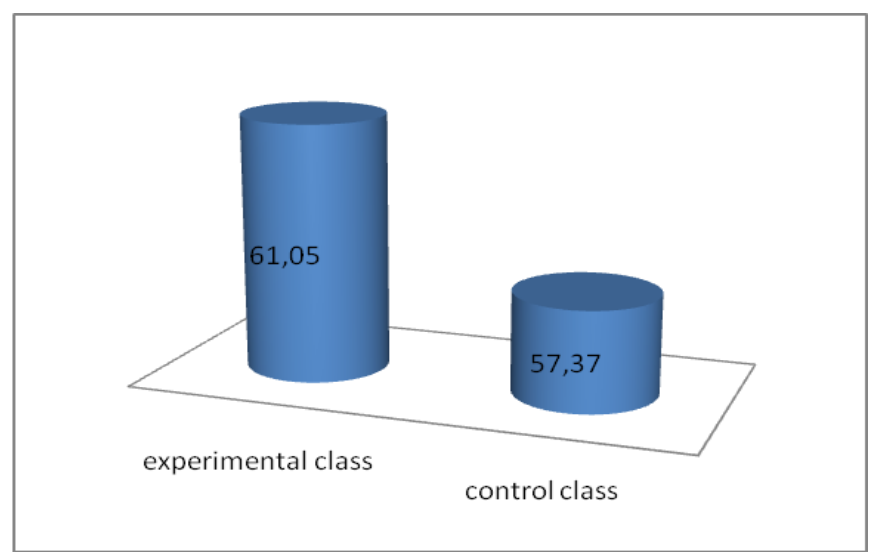

Fig 3. Distribution of Average Score Class and Class Experiment Control

Based on the data obtained, the authors also calculate the size of the effect (effect size, abbreviated ES) of the mean value. The simplest and most direct way to calculate the effect size on an average of the $\mathrm{d}$-Cohen method is to divide the average difference of the class by the combined standard deviation (standard deviation of two classes). The results of the calculation obtained an ES value of 0.27 (rounded to 0.3). Based on the criteria proposed by Cohen on the effect size, the value of 0.3 is in the range: $0.2<\mathrm{d}<0.8$ which means that the ES is moderate (mean difference of about 0.5 deviation standard).

These results can be compared with other research results with different mean values of population comparison (Somayasa et al, 20013). The average trend has a significant difference that can be found in its ES value of 0.27 (rounded to 0.3 ). This value, 
if confirmed with the interpretation table, indicates that the information obtained with the ES value is reduced (PS $=62$, $\mathrm{PNO}=21.3 \%$ ). It can be interpreted that the contribution of the effect of the treatment on the experimental class (class $8 \mathrm{E}$ ) if sought in the form of the percentage, is about $21 \%$. While the rest around $79 \%$ contributed to other factors not examined in this study.

\subsection{Analysis of student response}

The meaning of an authentic evaluation can be seen through the students' answers to the application of the authentic judgment itself. The student's answer is given to the teacher for the implementation of the mathematics learning assessment process. The results of the related research are presented in the following frequency data.

Table 9. Classification Values Student Response to Authentic Assessment

\begin{tabular}{|c|c|c|c|}
\hline Score Interval & Category & Frequency & $\begin{array}{c}(\%) \\
\text { Frequency }\end{array}$ \\
\hline $30-54$ & Very Low & 0 & 0 \\
\hline $55-78$ & Low & 7 & 18 \\
\hline $79-102$ & Average & 23 & \\
\hline $103-127$ & High & 8 & \\
\hline $128-150$ & Very High & 0 & 0 \\
\hline \multicolumn{2}{|c|}{ Total } & 38 & $100 \%$ \\
\hline
\end{tabular}

Table 9 shows that the prevalence of student response categories is at a moderate level (percentage rate $>60 \%$ ). If interpreted in general, this shows that there is a significant effect of treatment with the application of the authentic assessment in the $8 \mathrm{E}$ class compared to no treatment in the control class (class 8B). If classified by the distribution of frequencies and intervals with categories "very high", "high", "moderate", "low", "very low", it can be seen from the following figure:

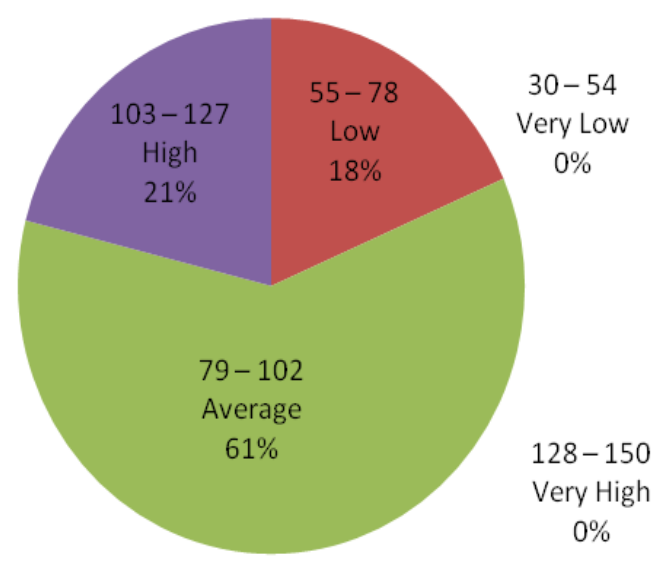

Fig. 4. Histogram Category Value Based Student Response Questionnaire scores
Students 'answers are classified by classifying each of the aspects studied with the respective indicators, in particular: (1) students' motivation; (2) contextual material; (3) questions; (4) work process; and (5) evaluation.

Referring to the results of the student's response, according to the theoretical study, motivation is a process to activate motive or power in action or behavior to meet the requirements and achieve certain goals (Kleinginna \& Kleinginna, 1981). In the context of learning, motivation is defined as the general driving force of students to perform a series of learning activities to achieve the goals set. The teacher's job is to generate the child's motivation so that he/she embarks on a series of learning activities. Students' motivation can arise from within the individual (intrinsic motivation) and can arise outside the student's self/extrinsic motivation (Kiemer, et al, 2015). Intrinsic motivation is the motivation that arises as a result within the individual without any compulsion and encouragement from others, such as a child who wants to learn because he wants to acquire knowledge or wants to acquire certain skills, will study diligently without any messenger from others. On the contrary, extrinsic motivation arises from the external influences of the individual, either by invitation, order or coercion by others, so that with such conditions he finally wants to learn.

Associated with the topics of mathematics, activities to promote student motivation are not easy to do. In some cases, students' lack of motivation can be triggered by (1) teacher teaching methods; (2) the implementation of the curriculum is not yet optimal; (3) there is no relevance of the curriculum for the needs and interests of the students; (4) students' economic and socio-cultural background; (5) advances in technology and information not used for positive things; (6) internal problems of the students themselves, for example, lack of trust and problems of the family environment. (Cobb, et al, 1991).

The results of this study are also consistent with the conclusions Kusmijati (2014), who have argued that the strong motivation to learn a foreign language will do things as well as possible, the activities that complete that require effort and skill, trying to be respectable, working on something important, trying to do something that is difficult with good and trying to do everything better than anyone else. The motivation to learn that authentic assessment if managed seriously should contribute to the ultimate in smooth learning and the achievement of learners.

Addressing material contextuality in principle is how the learning approaches imparted by teachers to explain learning materials and share each other with experience-oriented students have for learning the concepts of principles and theories (Johnson, 2002). Furthermore, contextual learning deals with: (1) the phenomena of the social life of society, language, the environment, hope and growing ideals; (2) the phenomenon of the world of student knowledge experience; (3) class as a social phenomenon.

Contextualization is a natural phenomenon, growing and growing and diversified in relation to the phenomenon of the social life of society. In this context, learning is basically an activity of activation, contact, connection, growth, development, and formation of understanding through the creation of activities, awakening, internalization, the process of finding answers to questions and rebuilding understanding through dynamic reflection. It is said that a process of teaching and learning is meaningful if students can relate lessons learned with real life that they live. (Kurniati et al, 2015). Thus, in contextual teaching it allows the occurrence of five important 
forms of learning, namely: (1) relative; (2) experience; (3) apply: (4) cooperate; (5) transfer.

\section{CONCLUSION}

Starting from the discussion in the previous chapter, the author presented some conclusions as follows; Based on the analysis of data and field findings on the use of authentic assessment in mathematics learning (cube-cube) on academic performance in Grade 8 SMP Negeri 2 Lemahabang Cirebon, there is an influence or positive contribution or statistically significant. For students, with this authentic assessment, their true ability will be more measurable. For teachers, it is expected that the existence of various forms of authentic assessment will facilitate them in setting up a truly appropriate measure to measure students' learning abilities.

The role of teachers in learning that includes an authentic assessment is required by asking questions that guide the achievement of a good learning class based on the steps (syntax) that have been established. The role of teachers in learning is as a student facilitator, so it is expected that he will know the benefits of learning for the students themselves. with the application of active learning experts.

\section{REFERENCES}

Becker, L.A. 2000. Effect Size (ES). Retrieved from http://web.uccs.edu/lbecker/Psy590/es.htm

Bergström, P. (2010). Process-based assessment for professional learning in higher education: Perspectives on the student-teacher relationship. The International Review of Research in Open and Distributed Learning, 11(2), 33-48.

Bloom, B. S. (1956). Taxonomy of educational objectives. Vol. 1: Cognitive domain. New York: McKay, 20-24.

Boediono. (2004). Statistika dan probabilitas. Bandung: Remaja Rosdakarya.

Breen, C. (2001). Coping with fear of mathematics in a group of preservice primary school teachers. Pythagoras, 54, 42-50.

Chang, L. (1994). A psychometric evaluation of 4-point and 6-point Likert-type scales in relation to reliability and validity. Applied psychological measurement, 18(3), 205-215.

Clotfelter, C. T., Ladd, H. F., \& Vigdor, J. L. (2006). Teacher-student matching and the assessment of teacher effectiveness. Journal of human Resources, 41(4), 778-820.

Cobb, P., Wood, T., Yackel, E., Nicholls, J., Wheatley, G., Trigatti, B., \& Perlwitz, M. (1991). Assessment of a problem-centered second-grade mathematics project. Journal for research in mathematics education, 3-29.

Cragg, L., \& Gilmore, C. (2014). Skills underlying mathematics: The role of executive function in the development of mathematics proficiency. Trends in Neuroscience and Education, 3(2), 63-68.

Departemen Pendidikan Nasional. (2006). Permendiknas No. 22 Tahun 2006 tentang standar isi. Jakarta: Depdiknas.

Departemen Pendidikan Nasional. (2007). Peraturan Menteri Pendidikan Nasional Nomor 20 Tahun 2007, tentang Standar Penilaian Pendidikan. Jakarta: Depdiknas

Detlefsen, M. (2013). Hilbert's program: an essay on mathematical instrumentalism (Vol. 182). New York: Springer Science \& Business Media.

Driscoll, M. P. (2000). Psychology of learning. Boston, Allyn and Bacon.

Ennis, R. H., \& Weir, E. E. (1985). The Ennis-Weir critical thinking essay test: An instrument for teaching and testing. Pacific Grove, CA: Midwest Publications.
Fonna, M., \& Mursalin, M. (2018). Role of Self-Efficacy Toward Students' Achievement in Mathematical Multiple Representation Ability (MMRA). Jurnal Ilmiah Peuradeun, 6(1), 31-40.

Fraenkel, J. R., Wallen, N. E., \& Hyun, H. H. (1993). How to design and evaluate research in education (Vol. 7). New York: McGraw-Hill.

Gittler, G., \& Glück, J. (1998). Differential transfer of learning: Effects of instruction in descriptive geometry on spatial test performance. Journal of Geometry and Graphics, 2(1), 71-84.

Hill, H. C., Rowan, B., \& Ball, D. L. (2005). Effects of teachers' mathematical knowledge for teaching on student achievement. American Educational Research Journal, 42(2), 371-406.

Istiqomah, W., \& Kariyoso, W. (2002). Psikologi Sosial. Jakarta: Karunika Universitas Terbuka Jakarta.

Johnson, E. B. (2002). Contextual teaching and learning: What it is and why it's here to stay. Corwin Press.

Kiemer, K., Gröschner, A., Pehmer, A. K., \& Seidel, T. (2015). Effects of a classroom discourse intervention on teachers' practice and students' motivation to learn mathematics and science. Learning and Instruction, 35, 94-103.

Klein, F., Beman, W. W., \& Smith, D. E. (2003). Famous problems of elementary geometry: the duplication of the cube, the trisection of an angle, the quadrature of the circle. Courier Corporation.

Kleinginna, P. R., \& Kleinginna, A. M. (1981). A categorized list of motivation definitions, with a suggestion for a consensual definition. Motivation and emotion, 5(3), 263-291.

Klopfer, L. E. (1971). Evaluation of learning in science. McGraw.

Kothari, C. R. (2004). Research methodology: Methods and techniques. New Age International.

Kunandar. (2013). Penilaian Autentik (Penilaian Hasil Belajar Peserta Didik Berdasarkan Kurikulum 2013). Jakarta: Rajawali Press.

Kurniati, K., Kusumah, Y. S., Sabandar, J., \& Herman, T. (2015). Mathematical critical thinking ability through contextual teaching and learning approach. Journal on Mathematics Education, 6(1), 53-62.

Kusmijati, N. (2014). Penerapan penilaian autentik sebagai upaya memotivasi belajar siswa. In Prosiding Seminar Nasional Hasil-hasil Penelitian dan Pengabdian LPPM (pp. 55-62).

McLeod, D. B., \& Adams, V. M. (Eds.). (2012). Affect and mathematical problem solving: A new perspective. Springer Science $\&$ Business Media.

Meltzer, D. E. (2002). The relationship between mathematics preparation and conceptual learning gains in physics: A possible "hidden variable" in diagnostic pretest scores. American journal of physics, 7O(12), 1259-1268.

Mertens, D. M. (2014). Research and evaluation in education and psychology: Integrating diversity with quantitative, qualitative, and mixed methods. USA: Sage publications.

Meyer, J., \& Land, R. (2003). Threshold concepts and troublesome knowledge: Linkages to ways of thinking and practising within the disciplines (pp. 412-424). Edinburgh: University of Edinburgh.

Muis, K. R., \& Edwards, O. (2009). Examining the stability of achievement goal orientation. Contemporary Educational Psychology, 34(4), 265-277.

Nitko, A. J., \& Brookhart, S. M. (2007). Educational assessment of student. Englewood Cliffs. NJ: Merrill Prentice Hall.

Pellegrino, J. W., \& Hilton, M. L. (2012). Education for Life and Work: Developing Transferable Knowledge and Skills in the 21st Century. National Academies Press.

Peraturan Menteri Pendidikan Nasional Republik Indonesia. (2007). Nomor 16 Tahun 2007 tentang Standar Kualifikasi Akademik dan Kompetensi Guru. Biro Hukum dan Organisasi Departemen Pendidikan Nasional.

Rusgianto, H. S. (2006). Hubungan antara sikap terhadap matematika, 
kecerdasan emosional dalam interaksi sosial di kelas dengan hasil belajar matematika siswa SMP Negeri 5 yogyakarta tahun 2006. Seminar Trend Penelitian dan Pembelajaran Matematika di Era ICT.

Sa'dijah, C. (2009). Asesmen Kinerja dalam Pembelajaran Matematika. Jurnal Pendidikan Inovatif, 4(2), 92-95.

Silver, E. A., \& Cai, J. (2005). Assessing Students' Mathematical Problem Posing. Teaching children mathematics, 12(3), 129.

Stiggins, R. J. (1994). Student-centered classroom assessment. New York: Merrill.

Trianto. (2009). Mendesain Model Pembelajaran Inovatif-Progresif. Jakarta: Kencana.

Van de Walle, J. A., Karp, K. S., \& Williams, J. M. B. (2007). Elementary and middle school mathematics.Teaching development. Boston: Pearson.

Wardhani, S. (2004). Penilaian pembelajaran matematika berbasis kompetensi. Modul Pelatihan. Diklat Instruktur/Pengembang Matematika SMK di PPPG Matematika Yogyakarta. Dirjen Pendidikan Dasar dan Menengah Pusat Pengembangan Penataran Guru (PPPG) Matematika. Yogyakarta, 7.

Widiarso, W. (2011). Mengaplikasikan uji-t untuk membandingkan Gain Score antar Kelompok dalam Eksperimen. Yogyakarta: FP UGM. 